\title{
IMPACT OF LEPTIN GENE POLYMORPHISMS ON MILK PRODUCTION TRAITS IN BARKI GOATS.
}

\author{
A. H. M. Ibrahim ${ }^{1 *}$, E. Ghoneim ${ }^{2}$, E. Faid-Allah ${ }^{2}$ \\ 1. Department of Animal Breeding, Desert Research Center, 1 Matehaf AlMatariya St.,Cairo \\ 11753, Egypt \\ 2. Department of Animal Production, Faculty of Agriculture, Minoufiya University, Egypt \\ * Corresponding author: adelhosseiny2005@yahoo.com
}

\begin{abstract}
The objective of this study was to test the association of variation in a $356 \mathrm{bp}$ region in exon 1 of the caprine leptin gene with milk production traits (milk yield (MY), milk fat content (FAT), milk protein content (PRO), milk lactose content (LAC), milk solid not fat content (SNF), pH and somatic cell count (SCC)) in 106 Barki does using polymerase chain reaction-single strand conformational polymorphism (PCR-SSCP). General linear model was used to test association between the variation in leptin and milk-production traits. The SSCP banding patterns for leptin revealed two variants ( $L 1$ and $L 2$ ), which contained two nucleotide sequence difference (c.670528A/G and c.670639T/C). The c. 670528A/G substitution results in the substitution of valine with alanine and c.670639T/C results in the substitution of arginine with histidine. Association analysis between the variation in leptin with milk production traits revealed that leptin genotype was associated $(P<0.05)$ with PRO and highly $(P<0.001)$ associated with MY. The presence of the $L 1$ variant in the doe genotype was significantly associated with lower MY $(\mathrm{P}<$ $0.01)$ and decreased PRO $(\mathrm{P}<0.01)$, whereas, the presence of the $L 2$ variant in the doe genotype was significantly associated with higher MY $(\mathrm{P}<0.05)$. The detected leptin variants showed significant $(\mathrm{P}<0.05)$ additive effect on $\mathrm{pH}$ and highly significant $(\mathrm{P}<0.01)$ dominance effects on MY and PRO. This suggests that selection for the leptin genotypes might increase milk production and milk protein content in Barki goats.
\end{abstract}

Keywords: Leptin, milk production traits, Barki goats.

\section{Introduction}

At the rural community, goats play an important role in the food chain and overall livelihoods of the poor Bedouins. The Barki goats breed is one of the main goat breeds in Egypt, and it is well adapted to the harsh desert conditions in the Mediterranean zone. Milk production traits have an important role regarding the supply of milk products for human consumption. Improving the productivity of goat milk is very important to decrease the gap of milk products and create an increase in the income of Bedouins who have most of goat flocks in Egypt.

There are two ways of selection for economically important traits like milk yield and milk traits. The first is conventional selection, which has shown slow genetic progress, especially for species with long generation intervals. The second is selection based on polymorphisms for specific genes that encode for protein products, which cause variation of desired traits.

Leptin is a hormone secreted by adipocytes and contributes in the control of energy balance. It affects the regulation of food intake, energy expenditure, fertility, milk production and immune functions (Blache et al., 2000; Liefers et al., 2002; Chilliard et al., 2005; Nkrumah et al., 2005; Singh et al., 2019). Circulating leptin concentrations reflect in part the amount of adipose tissue in ruminants body (Chilliard et al., 2001).

The role of leptin in milk synthesis was approved by the failure of milk production in the ob/ob female mouse after normal delivery (Moschos et al. 2002). During pregnancy, the level of leptin was increased in the dam when mammary epithelial cell proliferation was initiated (Moschos et al. 2002). This evidence confirms that leptin could be linked to mammary gland growth, which is a necessity 
for occur of lactation. Leptin was also found to have a strong relationship with prolactin, a hormone that stimulates milk secretion (Feuermann et al. 2009).

Leptin is encoded by leptin gene, which locate on Chromosome 4 and consists of three exons and two introns in goats.

Several polymorphisms of leptin gene have been described in cattle (Konfortov et al., 1999; Liefers et al., 2005) and were found to associate with serum leptin concentration (Liefers et al. 2003; Nkrumah et al., 2005), feed intake, energy balance and fertility (Liefers et al., 2005; Buchanan et al., 2003), milk energy output (Banos et al., 2008; Madeja et al., 2004), milk composition (Glantz et al., 2011), energy storage (Corva et al., 2009; Yang et al., 2007) and growth and milk production (Clempson et al., 2011).

Information is inadequate about leptin gene variation and its association with milk production traits in goats. Therefore, the present investigation intended to detect variation in the leptin gene and its association with milk production traits in Barki goats.

\section{Materials and Methods}

\section{Animal resources and milk samples}

Milk samples of 106 does were collected from January to March 2018 from 9 goat farms that owned by the Bedouins of the Northeast coast of Egypt. Goats graze daily for several hours on pastures and are also offered concentrated supplements when back for housing. Three monthly test-day were conducted for each doe. In each test, does were hand-milked in the morning, and the yield from each doe was measured using graduated measuring cylinders. Milk samples of $50 \mathrm{~mL}$ were collected and aseptically preserved using the Broad Spectrum Microtabs II tablets (Bentley Instruments EU, Maroeuil, France), and stored at $20^{\circ} \mathrm{C}$ until analyzed.

For samples, the chemical composition was assessed by infrared analysis using a MilkoScan instrument (MilkoScan 6000, Foss Electric A/S, Hillerød, Denmark), and by flow cell cytometry for somatic cell count (SCC) using the Fossomatic TM (FC, FOSS $®$, Foss Electric). Fat (FAT), protein (PRO) and lactose
(LAC) contents in the milk were expressed in $\mathrm{g} / 100 \mathrm{~mL}$. The contents of non-fat milk solids (SNF) expressed in $\mathrm{g} / 100 \mathrm{~mL}$. The logarithmic value of somatic-cell count in milk was recorded.

\section{Polymerase chain reaction}

Blood samples from all does were collected from the jugular vein using vacuum tubes treated with $0.25 \%$ EDTA. DNA was extracted using a genomic DNA extraction kit (Qiagen, Hilden, Germany).

A pair of specific primers was designed to amplify a $356 \mathrm{bp}$ fragment located in the exon 1 region of the caprine leptin gene based on the caprine leptin gene sequence (GenBank accession no. XP_017902457.1).The sequences of these two primers are as follows: F:, (F: 5 'CGTGTGTGAGATGTCATTGATCC -3`; R: 5 -AGGGGAATGCATTTCATTACTGTT $\left.3^{\prime}\right)$. All PCR reactions were carried out in a total volume of $25 \mu \mathrm{l}$ containing $0.30 \mu \mathrm{M}$ of each primer, $1 \mathrm{X}$ of high fidelity reaction buffer (500 mM KCl, $100 \mathrm{mM}$ Tris- $\mathrm{HCl}, \mathrm{pH} 8.3), 2$ $\mathrm{mM}$ of $\mathrm{MgCl} 2,200 \mu \mathrm{M}$ of $\mathrm{dNTP}$ and $0.7 \mathrm{U}$ of Taq DNA polymerase. Reaction parameters were: denaturation at $94^{\circ} \mathrm{C}$ for $2 \mathrm{~min}$, followed by 35 cycles of $94^{\circ} \mathrm{C}$ for $30 \mathrm{sec}, 59^{\circ} \mathrm{C}$ for $30 \mathrm{sec}$ and $72^{\circ} \mathrm{C}$ for $30 \mathrm{sec}$. The final extension was at $72^{\circ} \mathrm{C}$ for $10 \mathrm{~min}$.

\section{Single strand conformational polymorphism}

The amplicons were prepared for electrophoresis as follows: $3 \mu \mathrm{l}$ of amplicon was mixed with $7 \mu \mathrm{l}$ of denaturing loading buffer $(95 \%$ formamide, $0.025 \%$ bromophenol blue, $0.025 \%$ xylene cyanol and 20 mM EDTA; all reagents from Sigma-Aldrich, St. Louis, Missouri). The mixture was heated to $105^{\circ} \mathrm{C}$ for $5 \mathrm{~min}$, rapidly cooled on wet ice and then was loaded on $16 \times 18 \mathrm{~cm} ; 12 \%$ acrylamide: bisacrylamide (37.5:1; Bio-Rad) gels. Electrophoresis was run, using Protein II xi cells (Bio-Rad), for $16 \mathrm{~h}$ at $200 \mathrm{v}$ and $25^{\circ} \mathrm{C}$ in $0.5 \mathrm{x}$ TBE buffer. Gels were silver stained according to the method of Byun et al. (2009).

\section{Sequencing and analysis of leptin variants}

Two separate amplicons from does with homozygous SSCP patterns were used as templates for direct DNA sequencing. The 
amplicons were purified using a PCR cleanup kit (GenElute, Merck KGaA, Darmstadt, Germany), and sent to the Macrogen sequencing company, (Seoul, South Korea), to be sequenced in both directions. DNA sequence analyses, alignments, translations, analysis and comparisons were undertaken using DNAMAN and DNASTAR software.

\section{Statistical analysis}

Hardey-Weinberg equilibrium was tested by comparing the observed and expected genotypic frequencies using $\chi^{2}$.

The effect of doe genotype or the absence/presence of variant on milk production traits were analyzed using repeated-measures analysis (PROC MIXED, SAS Institute 2002) using the following model:

$\mathrm{Y}_{\mathrm{ijkl}}=u+\mathrm{G}_{\mathrm{i}}+\mathrm{F}_{\mathrm{j}}+\mathrm{P}_{\mathrm{k}}+(\mathrm{GF})_{\mathrm{ij}}+(\mathrm{GP})_{\mathrm{ik}}+$ $(\mathrm{FP})_{\mathrm{jk}}+\mathrm{e}_{\mathrm{ijk}}$;

where:

$\mathrm{Y}_{\mathrm{ijkl}}=$ the evaluated milk production traits;

$u=$ the overall mean;

$G_{i}=$ the fixed effect of $\mathrm{i}^{\text {th }}$ leptin genotype ( $\mathrm{i}=$

$1,2,3)$ or the fixed effect of the presence/absence of each leptin variant $(\mathrm{i}=0$, $1)$;

$F_{j}=$ the fixed effect of $\mathrm{j}^{\text {th }}$ farm $(\mathrm{j}=1, . .9)$;

$P_{k}=$ the fixed effect of $\mathrm{k}^{\text {th }}$ parity of doe $(\mathrm{k}=1$, $2,3)$;

$(G F)_{i j}=$ the interaction between the $\mathrm{i}^{\text {th }}$ genotype and $\mathrm{j}^{\text {th }}$ farm;

$(G P)_{i k}=$ the interaction between the $\mathrm{i}^{\text {th }}$ genotype and $\mathrm{k}^{\text {th }}$ parity of doe;

$(F P)_{j k}=$ the interaction between the $\mathrm{j}^{\text {th }}$ farm and $\mathrm{k}^{\text {th }}$ parity of doe;

$e_{i j k l m}=$ Random error; assumed N.I.D. $\left(0, \mathrm{r}^{2} \mathrm{e}\right)$.
Comparison of least square means between doe genotype groups or the absence/presence of variants for the milk production traits were analyzed using the linear model (PROC GLM, SAS Institute 2002).

The SAS software was also used to estimate the additive and dominance effects of single variant in the studied gene. To estimate the additive effect of variant $L 1$ relative to the other variant (L2), the genotypes were coded according to the 'number of copies' of variant $L 1: L 1 L 1=2$; $L 1 L 2=1$; and $L 2 L 2=0$. To estimate the dominance effect of variant $L 1$, genotypes were coded according to the 'presence' of variant $L 1$ : $L 1 L 1$ or $L 1 L 2=1$; and $L 2 L 2=0$.

\section{Results}

\section{Sequence variation}

Three different SSCP banding patterns were observed from amplicons of the amplified region of leptin gene (Fig. 1) and exhibited three genotypic polymorphisms (coded as: $L 1 L 1, L 1 L 2$ and $L 2 L 2$ with frequencies of 0.51 , 0.31 and 0.18 , respectively), representing two variants $L 1$ and $L 2$ with frequencies of 0.67 and 0.33 , respectively). Sequencing the amplicons that represent the detected variants revealed two different DNA sequences derived from two identified SNPs (c.670528A/G and c.670639T/C; Figure 2). The c. 670528A/G substitution resulted in the substitution of valine with alanine and c.670639T/C resulted in the substitution of arginine with histidine.

Chi-square $\left(\chi^{2}\right)$ test did not confirm HardyWeinberg equilibrium for the detected variants in the studied locus, which could be mainly a result of non-random mating or due to the little number of the studied animals.

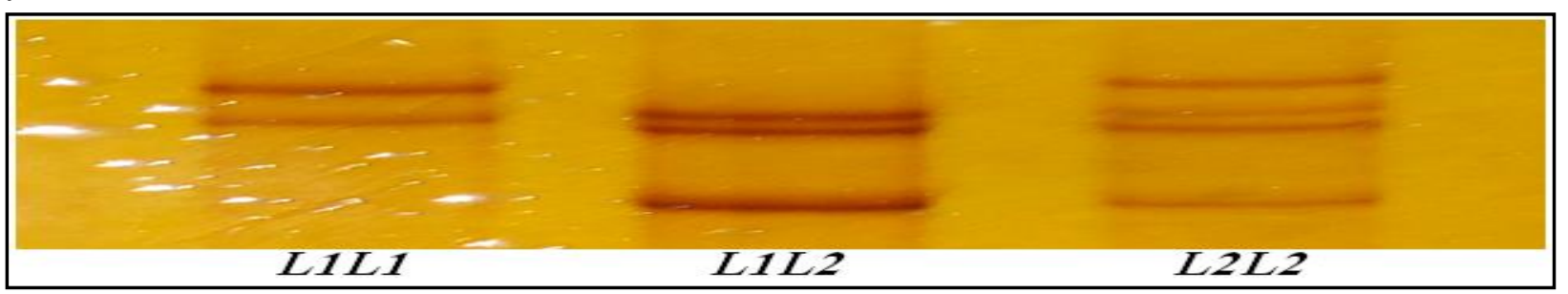

Figure 1. Polymerase chain reaction (PCR)-single-strand conformational polymorphism of caprine leptin. Three banding patterns corresponding to two variant sequences L1 and L2. 
Impact of leptin gene polymorphisms on milk production traits in Barki goats.

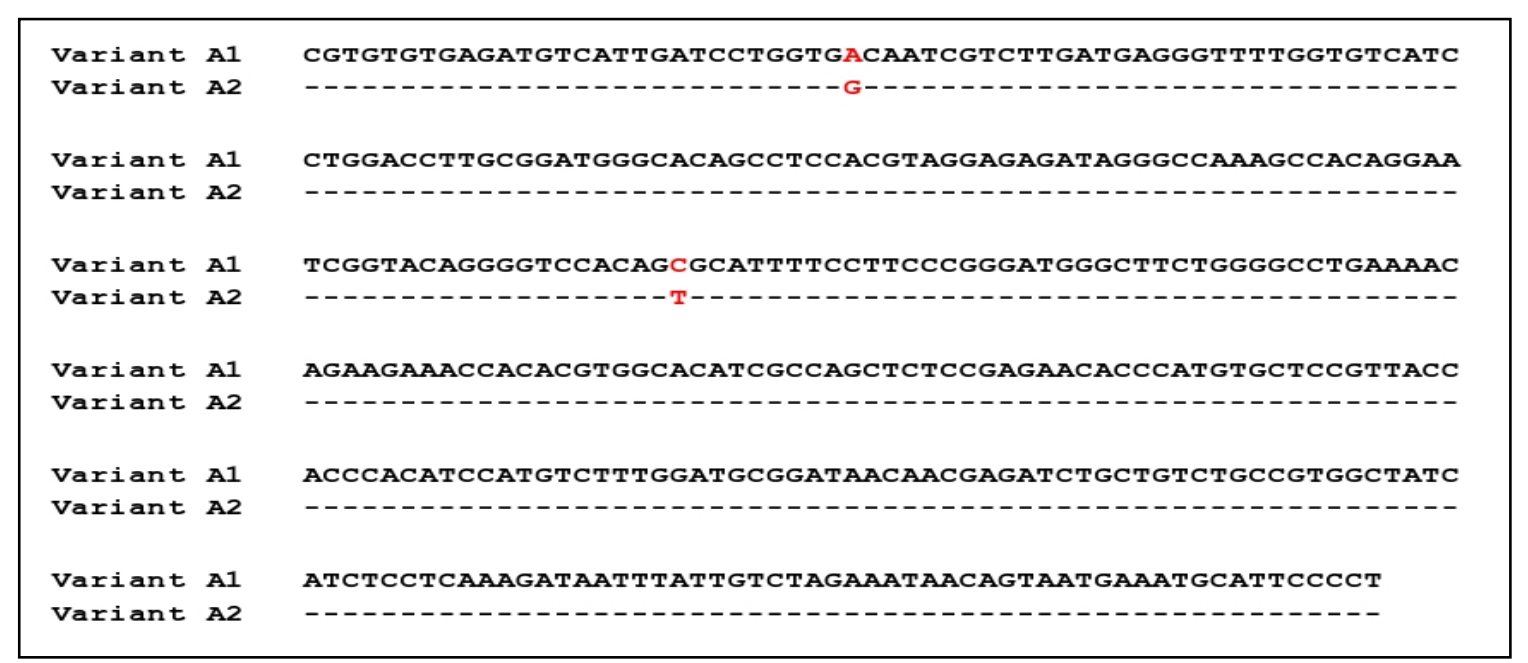

Figure 2. Sequences of the two detected variants in exon 1of leptin gene in Barki goats.

\section{Effect of non-genetic factors and their interaction with doe genotype on milk production traits}

The effects of non-genetic factors and their interaction with doe genotype on milk production traits are presented in Table 1. Farm showed significant effects $(\mathrm{P}<0.05 ; \mathrm{P}<0.01$; $\mathrm{P}<0.001)$ on the studied traits, furthermore doe parity significantly affected MY $(\mathrm{P}<.01)$ and PRO $(\mathrm{P}<0.05)$. The interaction between doe genotype and farm showed significancy $(\mathrm{P}<$ .001) only on MY; whereas, the interaction between doe genotype and doe parity showed significant effect $(\mathrm{P}<.05)$ on $\mathrm{MY}$ and $\mathrm{PRO}$. While, the interaction between parity and farm had no significant effect on all the studied traits.

\section{Effect of leptin genotype}

The associations of the detected leptin genotypes with milk production traits are presented in Table 2. A significant effect $(\mathrm{P}<$ $.05)$ of leptin genotypes was observed for PRO. In addition, a highly significant effect $(\mathrm{P}<$ .001) was observed for the leptin genotype on MY. The obtained results also revealed that does with the L2L2 genotype had superior performance for MY; however, does with the L1L1 genotype had the lowest performance for this trait. Additionally, L2L2 does were higher than L1L1 does in PRO. While, genotype had no significant effect on others milk traits.

\section{Effect of the presencelabsence of leptin variants}

The association between the presence/absence of the detected leptin variants in the doe genotype and milk production traits are presented in Table 3 . These results showed that the presence of the $L 1$ variant in the doe genotype was significantly associated with lower MY $(-0.31 \mathrm{~kg} / \mathrm{d} ; \mathrm{P}<.01)$ and decreased PRO $(-0.42 \%$; $\mathrm{P}<.01)$. Furthermore, the presence of the $L 2$ variant in the doe genotype was significantly associated with higher MY $(0.15 \mathrm{~kg} ; \mathrm{P}<.05)$.

\section{Genetic effects}

The genetic effects (additive/ dominance) of the detected leptin variants on milk production traits were tested and are presented in Table 4. The results showed significant additive effect $(\mathrm{P}$ $<.01)$ on $\mathrm{pH}(-0.035 \pm 0.016)$ and highly significant $(\mathrm{P}<.01)$ dominance effects on MY $(-0.317 \mathrm{~g} / \mathrm{d} \pm 0.114)$ and PRO $(-0.426 \%$ $\pm 0.142)$. 
Table (1). Significance effect of genetic, non-genetic factors and their interactions on growth traits and body indices of Barki lambs.

\begin{tabular}{|l|c|c|c|c|c|c|c|}
\hline \multirow{2}{*}{\multicolumn{1}{|c|}{ Factor }} & \multicolumn{7}{|c|}{ Trait } \\
\cline { 2 - 8 } & MY & FAT & PRO & LAC & SNF & pH & SCC \\
\hline Genotype & $* *$ & $\mathrm{~ns}$ & $*$ & $\mathrm{~ns}$ & $\mathrm{~ns}$ & $\mathrm{~ns}$ & $\mathrm{~ns}$ \\
\hline Farm & $* * *$ & $* *$ & $* *$ & $* *$ & $* * *$ & $*$ & $* * *$ \\
\hline Parity & $* *$ & $\mathrm{~ns}$ & $*$ & $\mathrm{~ns}$ & $\mathrm{~ns}$ & $\mathrm{~ns}$ & $\mathrm{~ns}$ \\
\hline Genotype $\times$ Farm & $* * *$ & $\mathrm{~ns}$ & $\mathrm{~ns}$ & $\mathrm{~ns}$ & $\mathrm{~ns}$ & $\mathrm{~ns}$ & $\mathrm{~ns}$ \\
\hline Genotype $\times$ Parity & $*$ & $\mathrm{~ns}$ & $*$ & $\mathrm{~ns}$ & $\mathrm{~ns}$ & $\mathrm{~ns}$ & $\mathrm{~ns}$ \\
\hline Parity $\times$ Farm & $\mathrm{ns}$ & $\mathrm{ns}$ & $\mathrm{ns}$ & $\mathrm{ns}$ & $\mathrm{ns}$ & $\mathrm{ns}$ & $\mathrm{ns}$ \\
\hline
\end{tabular}

MY: milk yield; FAT: fat content; PRO: protein content; LAC: lactose content; SNF: solid not fat; SCC: somatic cell count; ns: non significant; *: refers to significance at $(\mathrm{p}<.05)$; **: refers to significance at $(\mathrm{p}<.01)$; ***: refers to significance at $(\mathrm{p}<.001)$.

Table 2. Least square means and their standard errors for milk production traits in Barki goats according to the leptin genotypes

\begin{tabular}{|l|c|c|c|c|}
\hline \multirow{2}{*}{ Trait } & \multicolumn{3}{|c|}{ Genotype } & \multirow{2}{*}{ P-value } \\
\cline { 2 - 4 } & $\begin{array}{c}\text { L1L1 } \\
(54)\end{array}$ & $\begin{array}{c}\text { L1L2 } \\
(33)\end{array}$ & $\begin{array}{c}\text { L2L2 } \\
(19)\end{array}$ & \\
\hline MY $(\mathrm{kg})$ & $1.22^{b} \pm 0.06$ & $1.264^{b} \pm 0.06$ & $1.558^{a} \pm 0.10$ & 0.001 \\
\hline FAT $(\mathrm{gm} / \mathrm{d})$ & $4.87 \pm 0.21$ & $4.81 \pm 0.25$ & $4.17 \pm 0.36$ & 0.721 \\
\hline PRO $(\mathrm{gm} / \mathrm{d})$ & $4.75^{b} \pm 0.07$ & $4.68^{b} \pm 0.10$ & $5.15^{a} \pm 0.13$ & 0.011 \\
\hline LAC $(\mathrm{gm} / \mathrm{d})$ & $4.92 \pm 0.07$ & $4.78 \pm 0.07$ & $5.05 \pm 0.07$ & 0.356 \\
\hline SNF $(\mathrm{gm} / \mathrm{d})$ & $10.61 \pm 0.08$ & $10.38 \pm 0.10$ & $10.56 \pm 0.14$ & 0.359 \\
\hline PH & $6.65 \pm 0.02$ & $6.72 \pm 0.02$ & $6.71 \pm 0.02$ & 0.423 \\
\hline SCC & $5.19^{a b} \pm 0.09$ & $5.43^{a} \pm 0.12$ & $5.02^{b} \pm 0.16$ & 0.148 \\
\hline
\end{tabular}

MY: milk yield; FAT: fat content; PRO: protein content; LAC: lactose content; SNF: solid not fat; SCC: somatic cell count; ns: non significant; *: refers to significance at $(\mathrm{p}<.05)$. 
Impact of leptin gene polymorphisms on milk production traits in Barki goats.

Table 3. Association of the absence/ presence of leptin variants with on milk production traits in Barki goats

\begin{tabular}{|c|c|c|c|c|c|c|c|}
\hline \multirow[b]{2}{*}{ Trait } & \multirow[b]{2}{*}{$\begin{array}{l}\text { Variant } \\
\text { being } \\
\text { assessed }\end{array}$} & \multicolumn{4}{|c|}{$\mathbf{L S M} \pm \mathbf{S E}$} & \multirow[b]{2}{*}{$\begin{array}{c}\text { Absolute } \\
\text { Increase/decrease }\end{array}$} & \multirow[t]{2}{*}{ Significance } \\
\hline & & $\mathbf{N}$ & $\begin{array}{l}\text { Absence } \\
\text { variant }\end{array}$ & $\mathbf{N}$ & $\begin{array}{c}\text { Presence } \\
\text { variant }\end{array}$ & & \\
\hline \multirow[t]{2}{*}{ MY (kg) } & L1 & 19 & $1.55 \pm 0.10$ & 87 & $1.24 \pm 0.05$ & -0.31 & $* *$ \\
\hline & $\mathbf{L} 2$ & 54 & $1.22 \pm 0.06$ & 52 & $1.37 \pm 0.06$ & 0.15 & $*$ \\
\hline \multirow[t]{2}{*}{ FAT } & L1 & 19 & $4.17 \pm 0.36$ & 87 & $4.85 \pm 0.16$ & 0.68 & $\mathrm{~ns}$ \\
\hline & L2 & 54 & $4.87 \pm 0.21$ & 52 & $4.58 \pm 0.21$ & -0.29 & $\mathrm{~ns}$ \\
\hline \multirow[t]{2}{*}{ PRO } & L1 & 19 & $5.15 \pm 0.13$ & 87 & $4.73 \pm 0.06$ & -0.42 & $* *$ \\
\hline & L2 & 54 & $4.76 \pm 0.07$ & 52 & $4.85 \pm 0.08$ & 0.09 & ns \\
\hline \multirow[t]{2}{*}{ LAC } & L1 & 19 & $5.05 \pm 0.08$ & 87 & $4.87 \pm 0.06$ & -0.18 & $\mathrm{~ns}$ \\
\hline & L2 & 54 & $4.92 \pm 0.08$ & 52 & $4.88 \pm 0.06$ & -0.04 & $\mathrm{~ns}$ \\
\hline \multirow[t]{2}{*}{ SNF } & $\mathbf{L 1}$ & 19 & $10.56 \pm 0.15$ & 87 & $10.52 \pm 0.07$ & -0.04 & ns \\
\hline & $\mathbf{L 2}$ & 54 & $10.61 \pm 0.09$ & 52 & $10.45 \pm 0.09$ & -0.16 & $\mathrm{~ns}$ \\
\hline \multirow[t]{2}{*}{ pH } & L1 & 19 & $6.71 \pm 0.02$ & 87 & $6.68 \pm 0.01$ & -0.03 & $\mathrm{~ns}$ \\
\hline & $\mathbf{L 2}$ & 54 & $6.65 \pm 0.02$ & 52 & $6.71 \pm 0.02$ & 0.06 & ns \\
\hline \multirow[t]{2}{*}{ SCC } & L1 & 19 & $5.02 \pm 0.16$ & 87 & $5.28 \pm 0.08$ & 0.26 & $\mathrm{~ns}$ \\
\hline & $\mathbf{L 2}$ & 54 & $5.19 \pm 0.09$ & 52 & $5.28 \pm 0.10$ & 0.09 & $\mathrm{~ns}$ \\
\hline
\end{tabular}

MY: milk yield; FAT: fat content; PRO: protein content; LAC: lactose content; SNF: solid not fat; SCC: somatic cell count; ns: non significant; *: refers to significance at $(\mathrm{p}<.05) ; * *$ : refers to significance at $(\mathrm{p}<.01)$.

Table 4. Genetic effects of the caprine leptin gene on milk production traits in Barki goats

\begin{tabular}{|l|c|c|c|c|}
\hline \multirow{2}{*}{ Trait } & \multicolumn{4}{|c|}{ Genetic effect } \\
\cline { 2 - 5 } MY & Additive & P-value & Dominance & P-value \\
\hline FAT & $-0.142 \pm 0.058$ & 0.055 & $-0.317 \pm 0.114$ & $0.006^{* *}$ \\
\hline PRO & $0.301 \pm 0.195$ & 0.126 & $0.682 \pm 0.387$ & 0.081 \\
\hline LAC & $-0.151 \pm 0.073$ & 0.051 & $-0.426 \pm 0.142$ & $0.003^{* *}$ \\
\hline SNF & $-0.029 \pm 0.065$ & 0.658 & $-0.179 \pm 0.129$ & 0.167 \\
\hline pH & $0.059 \pm 0.082$ & 0.471 & $-0.043 \pm 0.162$ & 0.791 \\
\hline SCC & $-0.035 \pm 0.016$ & $0.026^{*}$ & $-0.035 \pm 0.032$ & 0.273 \\
\hline
\end{tabular}

MY: milk yield; FAT: fat content; PRO: protein content; LAC: lactose content; SNF: solid not fat; SCC: somatic cell count; ns: non significant; *: refers to significance at $(\mathrm{P}<.05) ; * *$ : refers to significance at $(\mathrm{P}<.01)$.

\section{Discussion}

This is the first report concerning the effect of leptin variation on milk production traits in Barki goats. The results suggest that the leptin variants in exon 1 are associated with milk yield and protein content. Studies regarding the effect of leptin genotypes on milk production traits in goats are missing in the literature; however there are many studies concerned the effect of variation in leptin gene on other economic traits in goats. Maitra et al. (2014) reported the complete sequence of leptin gene in Indian 
goats by direct sequencing and detected seven SNPs: these SNPs were found in exon 2 (g.1029T C), intron 2 (g.1621G A) and 3'UTR (g.3968T C, g.3971C T, g.4026G A, g.4105G A and g.4225T C). Wang et al. (2015) identified genetic variants of the leptin gene in five Chinese goat breeds, and detected six novel single nucleotide polymorphisms (SNPs) (g.117T > C, g.1642G > A, g.2883G > A, g.3053T > C, g.3190G > A, and g.3314T > C); all of these six SNPs are associated with growth traits. Avondo et al. (2019) stated that leptin genotype in the SNP at position (c.483T $>\mathrm{A}$ ) strongly affected fatty acid composition (the levels of monounsaturated fatty acids and polyunsaturated fatty acids, desaturation index and favorable atherogenic index) in Girgentana lactating goats.

In dairy cattle, the allelic variation $(\mathrm{C}$ to $\mathrm{T}$ transition in exon 2 of ovine leptin gene that results in an Arg25Cys) was associated with milk yield and SCC in Holstein cows (Buchanan et al., 2003). The same SNP was tested for Holstein First-Calf Heifers and found to affect milk yield, fat mass fraction, milk fat yield, and milk protein yield (Balakirev et al., 2018). Other SNPs (UASMS1, UASMS2, C963T, E2FB, A59V, T945M, A1457G, NPY1 and A252T) were genotyped across a population of Holstein cows, and only one of these SNPs (A59V) affected milk production (Clempson et al., 2011). De Matteis et al. (2012) fully characterized the leptin gene by sequencing the whole coding region and part of the 5' flanking region in Holstein cows and revealed a total of 26 SNPs (24 in the promoter and 2 in the exons). Of the 26 detected SNP, 19 already were reported by Liefers et al. (2005) (accession no. AJ571671); three SNP were reported in the dbSNP (rs29004171; rs29004172; rs29004173); one SNP (accession no. AB070368) previously were reported by Orrù et al. (2012) and two SNP (rs29004488 and rs29004508) had been reported by Konfortov et al. (1999). Finally, a novel SNP, LEP05, was detected in the present study (g.2003435T $>$ C; accession no. NW_001494939). None of these SNPs affected milk production traits. Maletic et al. (2019) detected leptin gene polymorphism on exon 3
(A59V locus) and intron 2 (SAU3AI locus) in the endangered population of autochtonous Busha cattle and tested their associations with milk traits; the first locus significantly affected only SNF content.

In buffalo, Tanpure et al. (2012) investigated genetic variations in intron 1 region of leptin gene using the PCR-SSCP and sequencing methods and reported the association of them with milk traits. This study revealed three SSCP variants $\mathrm{A}, \mathrm{B}$ and $\mathrm{C}$ among nine breeds of buffaloes (Mehsana, Marathwada, Chilika, Jaffarabadi, Murrah, Nili-Ravi, Toda, Pandharpuri and Nagpuri) that were derived from five polymorphic sites, with three haplotypes. The study revealed significantly high fat percentage at 150 days in SSCP variant $\mathrm{B}$ in Mehsana breed.

The effect of leptin on milk production and protein content in goats might be attributable to its effects on feed intake and energy balance. Many investigations have shown associations between milk production traits and these traits. Nogalski et al. (2012) reported that the negative energy balance is followed by excessive fat mobilization in the body results in an increased fat and decreased protein content in milk. They also stated that the rise in milk fat stems from the increased amount of free fatty acids in the blood. The reduction in milk protein resulting from a delay in the protein production processes that require energy when there is shortage of available energy. Singh et al. (2019) reviewed that, during pregnancy, leptin levels are high and they decline rapidly towards parturition. Eliminating the energetic costs of lactation by preventing milk delivery in cows caused an increase in plasma leptin levels together with an increase in energy balance. This indicates that the fall in circulating leptin levels towards and during lactation is due to the energetic costs of milk production. Pickavance et al. (1998) observed that the increase in leptin induced by food intake was eliminated during lactation and they speculated that the hypoleptinemia may be an important factor promoting the hyperphagia of lactation. They also demonstrated that the onset of the negative energy balance is largely responsible of declining leptin concentrations towards 
parturition and that the low leptin levels during lactation probably induce the hyperphagia of lactation.

It is notable that the detected variants of leptin gene showed negative dominance effects on MY and PRO. These results indicate that the best way to improve the productivity of goats from milk and protein content is crossing between the endogenous and elite breeds of goats

\section{Conclusion}

This study is the first concerning the effect of leptin gene polymorphisms on milk production traits in Barki goats. We conclude that the variation in the caprine leptin gene has an effect on milk yield and milk protein content. However, further investigations on a larger population of Barki goats or other breeds of goats are needed to confirm these results before being recommended to breeding programs for improving milk production traits in goats.

\section{Acknowledgments}

The authors thanks the help of the members of the project "Application of developmental and improvement breeding programs for camels and small ruminants in the North West coast of Egypt”, especially, Dr. Hasan Shafie, Dr. Adel Mahrous and Prof. Tarik Ramadan.

\section{REFERENCES}

Avondo, M., A. Di Trana, B. Valenti, A. Criscione, S. Bordonaro, A. De Angelis, D. Giorgio and P. Di Gregorio (2019). Leptin gene polymorphism in goats fed with diet at different energy level: Effects on feed intake, milk traits, milk fatty acids composition, and metabolic state. Animals, 9: 424.

Balakirev N., N. Y. Saphina, Y. R. Yulmeteva, S. K. Shakirov and F. F. Zinnatova. (2018). Association of Leptin Gene (LEP) Polymorphism with Growth Rates and Milk Production in Holstein First-Calf Heifers. Russian Agricultural Sciences, 44: 460-464.

Banos G., J. Woolliams, B. Woodward, A. Forbes and M. Coffey. (2008) Impact of single nucleotide polymorphisms in leptin, leptin receptor, growth hormone receptor, and diacylglycerol acyltransferase (DGAT1) gene loci on milk production, feed, and body energy traits. Journal of Dairy Science, 91: 3190-3200.

Blache, D., R. Tellam, L. Chagas, M. Blackberry, P. Vercoe and G. Martin. (2000). Level of nutrition affects leptin concentrations in plasma and cerebrospinal fluid in sheep. The Journal of endocrinology, 165: 625-637.

Buchanan C., A. Van Kessel, C. Waldner, D. Christensen, B. Laarveld and S. Schmutz (2003). Hot Topic: An Association between a Leptin Single NucleotidePolymorphism and Milk and Protein Yield Journal of Dairy Science, 86: 3164-3166.

Byun S., Q. Fang, H. Zhou and J. Hickford (2009). An effective method for silver-staining DNA in large numbers of polyacrylamide gels. Analytical Biochemistry, 385: 174-175.

Chilliard Y., C. Delavaud and M. Bonnet. (2005). Leptin expression in ruminants: Nutritional and physiological regulations in relation with energy metabolism. Domestic animal endocrinology, 29: 3-22.

Chilliard Y., M. Bonnet, C. Delavaud, Y. Faulconnier, C. Leroux, J. Djiane and F. Bocquier (2001). Leptin in ruminants. Gene expression in adipose tissue and mammary gland, and regulation of plasma concentration. Domest Anim Endocrinol, 21: 271-295.

Clempson A., G. Pollott, J. Brickell, N. Bourne, N. Munce and D. Wathes (2011). Evidence that leptin genotype is associated with fertility, growth, and milk production in Holstein cows. Journal of Dairy Science, 94: 3618-3628.

Corva P.M., G. Fernandez Macedo, L. Soria, J. Papaleo Mazzucco, M. Motter, A. Villarreal Schor, C. Mezzadra, L. Melucci and M. Miquel (2009). Effect of leptin gene polymorphisms on growth, slaughter and meat quality traits of grazing Brangus steers. Genetics and Molecular Research, 8: 105-116.

De Matteis G, M. Scatà, F. Grandoni, F. Petrera, F. Abeni, G. Catillo, F. Napolitano and B. Moioli (2012). Association analyses of single nucleotide polymorphisms in the leptin and leptin receptor genes on milk and morphological traits in Holstein cows. Open Journal of Animal Sciences, 2: 174-182. 
Feuermann Y., S. Mabjeesh and A. Shamay (2009). Mammary Fat Can Adjust Prolactin Effect on Mammary Epithelial Cells via Leptin and Estrogen. International Journal of Endocrinology, 2009: 427260.

Glantz M., M. Lindmark Mansson, H., Stalhammar, H. and Paulsson, M. (2011) Effect of polymorphisms in the leptin, leptin receptor and acyl-CoA:diacylglycerol acyltransferase 1 (DGAT1) genes and genetic polymorphism of milk proteins on bovine milk composition. Journal of Dairy Research, 30: $1-9$

Konfortov B., V. Licence and J. Miller (1999). Re-sequencing of DNA from a diverse panel of cattle reveals a high level of polymorphism in both intron and exon. Mammalian Genome, 10: 1142-1145.

Liefers S., M. Te Pas, R. Veerkamp and T. van der Lende (2002). Associations between leptin gene polymorphisms and production, live weight, energy balance, feed intake, and fertility in Holstein heifers. Journal of Dairy Science, 85: 1633-1638.

Liefers S., M. Te Pas, R. Veerkamp,Y. Chilliard, C. Delavaud, R. Gerritsen and T. Van der Lende (2003) Association of leptin gene polymorphisms with serum leptin concentration in dairy cows. Mammalian Genome, 14: 657-663.

Liefers S., R. Verkamp, M. Te Pas, C. Delavaud, Y. Chilliard, M. Platje and T. Van der Lende (2005) Leptin promoter mutations affect leptin levels and performance traits in dairy cows. Animal Genetics, 36: 111- 118.

Madeja Z., T. Adamowicz, A. Chmurzynska, T. Jankowski, J. Melonek, M. Switonski and T. Strabel (2004). Short communication: Effect of leptin gene polymorphisms on breeding value for milk production traits. Journal of Dairy Science, 87: 3925-3927.

Maitra A., R. Sharma, A. Pandey, L. Singh, S. Mandakmale and B. Mishra (2014). Preliminary identification and characterisation of leptin gene polymorphism in Indian goats. Journal of Applied Animal Research, 42: 118122 .

Maletic M., N. Papriki, M. Lazarevic, A. Hodzic, V. Davidovic, L. Stanisic and Z.
Stanimirovic (2019). Insight in leptin gene polymorphism and impact on milk traits in Autochtonous Busha cattle. Acta VeterinariaBeograd, 69: 153-163.

Moschos S., J. Chan and C. Mantzoros (2002). Leptin and reproduction: a review. Fertility and Sterility, 77: 433-444.

Nkrumah J., C. Li, J. Yu, C. Hansen, D. Keisler and S. Moore (2005). Polymorphisms in the bovine leptin promoter associated with serum leptin concentration, growth, feed intake, feeding behavior, and measures of carcass merit. Journal of Animal Science, 83: 20-28.

Nogalski Z, M. Wroński, M. Sobczuk-Szul, M. Mochol and P. Pogorzelska (2012). The Effect of Body Energy Reserve Mobilization on the Fatty Acid Profile of Milk in High-yielding Cows. Asian-Australas Journal of Animal Science, 25: 1712-1720.

Orrù L, G. Terzano, F. Napolitano, M.

Savarese, G. De Matteis, M. Scatà, G. Catillo and B. Moioli (2007). DNA Polymorphisms in River Buffalo Leptin Gene. Italian Journal of Animal Science, 6 (Suppl. 2): 342-344.

Pickavance L., M. Tadayon, G. Williams and R. Vernon (1998). Lactation suppresses diurnal rhythm of serum leptin. Biochemical Biophysical Research Communications, 248: 196-199.

[SAS] Statistics Analysis System. 2002. Statistics Analysis System: User's guide (Ver 9). North Carolina (US): SAS Institute Inc.

Singh S., A. Singh and M. Vaidya (2019). Leptin as a Metabolic and Energy Homeostatic Hormone in Dairy Animals-A Review. Indian Journal of Animal Nutrition, 29: 109-116

Stergios M., L. Jean, M. Chan and S. Christos S. Mantzoros (2002). Leptin and reproduction: a review. Fertility and Sterility, 77: 433-44.

Tanpure T., P. Dubey, P. Kathiravan, B. Mishra, S. Niranjan and R. Kataria (2012). PCR-SSCP analysis of leptin gene and its association with milk production traits in river buffalo (Bubalus bubalis). Tropical Animal Health and Production, 44: 1587-1592.

Wang C, H. Zhang, L. Niu, J. Guo, X. Jia, L. Wang, L. Li, H. Zhang and T. Zhong (2015). 
Impact of leptin gene polymorphisms on milk production traits in Barki goats.

The novel SNPs of leptin gene and their associations with growth traits in Chinese Nanjiang Yellow goat. Gene, 572: 35-41.

Yang D., H. Chen, X. Wang, Z. Tian, L. Tang, Z. Zhang, C. Lei, L. Zhang and Y. Wang (2007) Association of polymorphisms of leptin gene with body weight and body sizes indexes in Chinese indigenous cattle. Journal of Genetics and Genomics, 34: 400-405.

\section{تأثير تعدد الأنماط لجين اللبتين على صفات إنتاج اللبن في ماعز البرقي

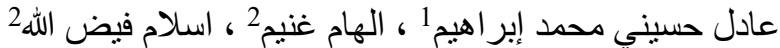

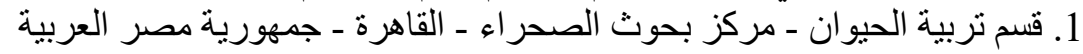

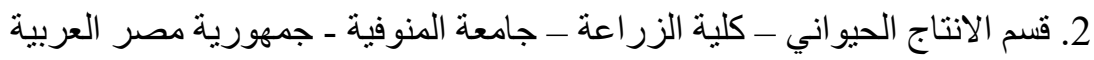

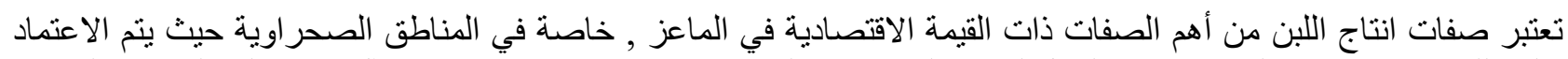

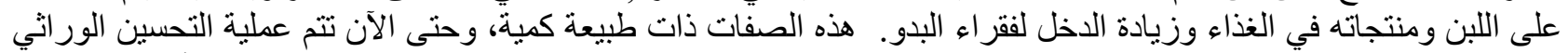

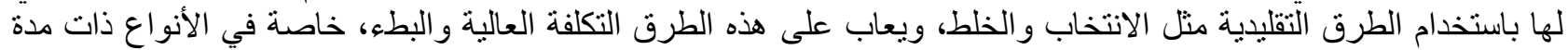
الجيل الطويلة مثل الأبقار و الأغنام.

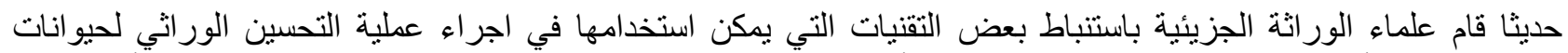

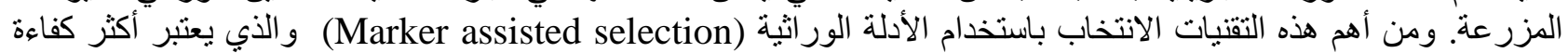
وسر عة ودقة مقارنة بالطرق التقليدية حيث أنه يمكن انتخاب الحيوان في مرحلة مبكرة من العمر اعتمادا على تركيبه الور اثئي

في هذه الدر اسة نم اختيار طريقة الجينات عظبمة التأثثر (candidate gene approach) ، لتحديد أدلة ور اثية انتخابية لصفات انتاج اللبن في الماعز البرقي.

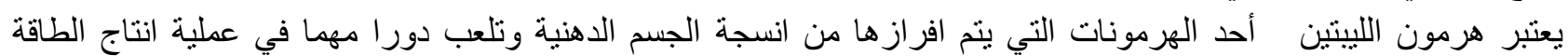

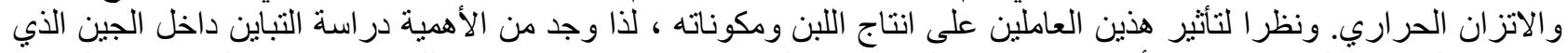

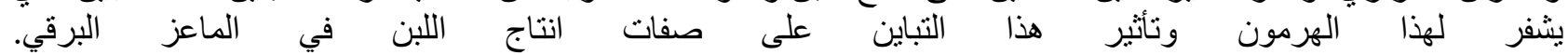

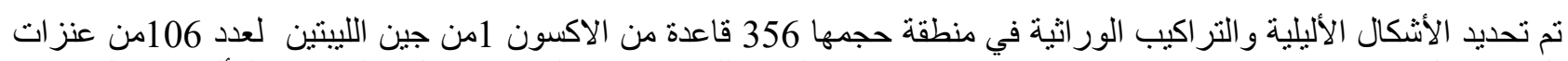

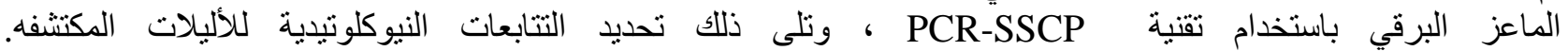

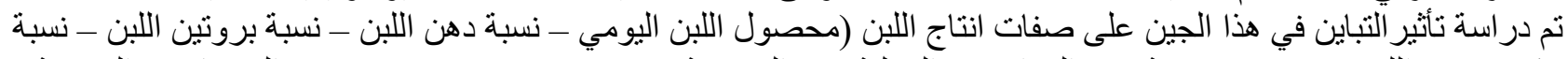

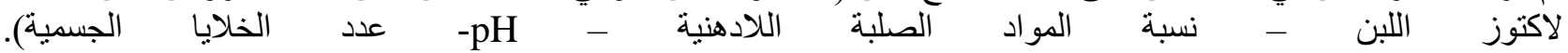

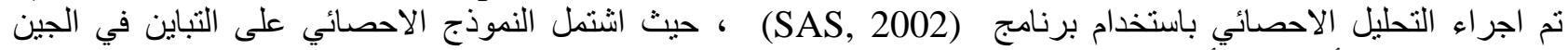

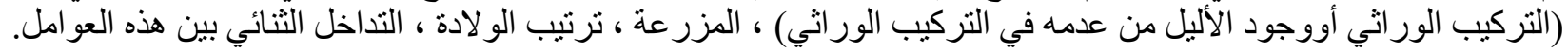
وكانت النتائج المتحصل عليها كالتالي

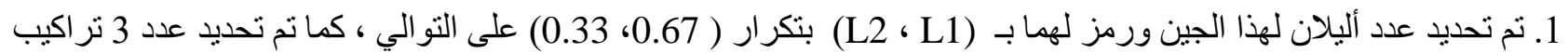

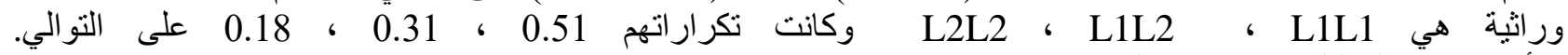
2.أثنتت نتائج التحليل الاحصائي الآتي:

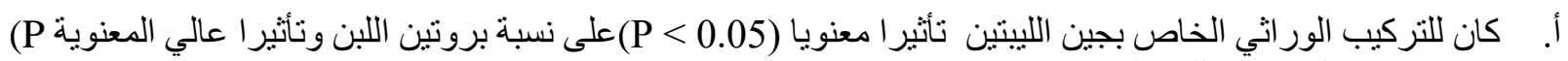

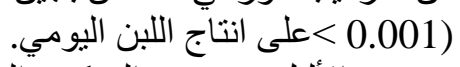
ب. أدى وجود الأليل L1 L1 في التركيب الور اثي لحدوث انخفاض عالي المعنوية (P > P.01) في محصول انتاج اللبن ونسبة بروتين اللبن.

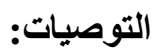

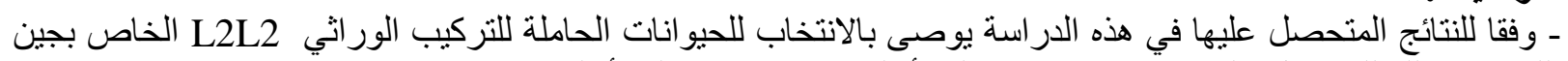

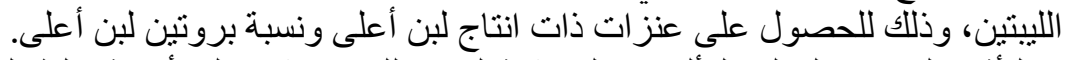

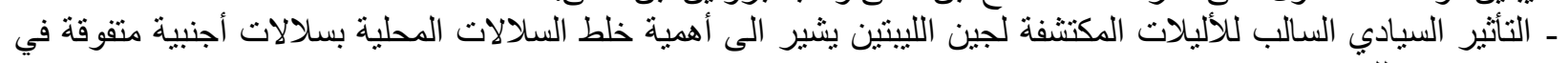
صفات انتاج اللبن. 